\title{
Combretastatin A-1
}

National Cancer Institute

\section{Source}

National Cancer Institute. Combretastatin A-1. NCI Thesaurus. Code C162344.

A stilbenoid orig inally isolated from the plant Combretum caffrum, with vasculardisrupting and antineoplastic activities. Upon administration, combretastatin A1 (CA1) promotes rapid microtubule depolymerization; endothelial cell mitotic arrest and apoptosis; destruction of the tumor vasculature; disruption of tumor blood flow; and tumor cell necrosis. In addition, orthoquinone intermediates, metabolized from combretastatin A1 by oxidative enzymes found to be elevated in some tumor types, may bind to tumor cell thiol-specific antioxidant proteins and DNA, and stimulate oxidative stress by enhancing superoxide/hydrogen peroxide production. 